\title{
EFFECTS OF ENERGY AND PROTEIN LEVELS ON FEED INTAKE AND NUTRIENT UTILIZATION BY YANKASA LAMBS
}

\author{
I.F. Adu, \\ National Animal Production Research Institute, Shika - Zaria.
}

\begin{abstract}
SUMMARY
TWENTY yearling Yankasa lambs were fed 2 levels of energy (2.4 and $2.9 \mathrm{ME} \mathrm{Mcal} / \mathrm{kg})$ and 2 levels of protein (11.3 and 16. 1\%) under each energy level for 100 days to study the effects of feed intake, digestibility and nutrient utilization. Groundnut top hay was the basal roughage while maize, wheat bran and cotton seed cake were the energy and proteis supplements in different proportions.

Hay intake decreased with increase in protein level. Dry matter digestibility significantly (P/0.05) increased with increase in both energy and protein levels. Crude protein digestibility was significantly (P/0.01) affected by proteln level but not by energy level. Crude fibre digestibility was depressed in the high-energy-high protein diet. The consumption of nutrients tended to be more on the high energy rations. Nitrogen retention was also significantly (P/0.05) higher on the high energy rations.

Liveweight gain was highest in the low energy/high protein group $(79.4 \mathrm{~g} / \mathrm{day})$ and lowest in the low energy/low protein group $(56.4 \mathrm{~g} / \mathrm{day})$. Within each energy level, liveweight gains increased with increase in protein level.

Animals fed high energy rations required more protein than those on low energy rations.
\end{abstract}

\section{INTRODUCTION}

Adu and Lakpini (1980) showed that the efficiency of utilization of nitrogen in high protein rations (as measured by nitrogen balance) is markedly affected by energy intake. Crampton (1964) and Preston (1966) in discussing the relationship between energy and protein concluded that protein requirement had little meaning unless energy requirement has been satisfied. There is abundant information on energy and protein interactions in a ration, but the results have not been consistent in the literature (Jones and Hogue, 1960; Prior, Kohlmeier, Cundiff, Dikeman and Crouse, 1977; Ferrell,
Kohlmeier, Crouse and Glimp, 1978; Singh, Singh and Patnayak, 1979). Not withstanding this inconsistencies, recent feeding systems adopt the energy to protein ratio concept to get maximum performance at low cost. This strongly support the contention that the effect of energy density and protein concentration in the diet on animal performance needs continuous investigation and review. This is even more relevant in our situation where information on ruminant nutrition is very limited. The objective of this experiment is therefore, to evaluate the effect of energy and protein levels on feed intake, nutrient digestibility and utilization by yearling Yankasa lambs.

\section{MATERIALS AND METHODS}

Twenty yearling Yankasa ram lambs were divided into 4 groups and fed 2 levels of energy and 2 levels of protein within each energy level in a randomized block design. Groundnut top hay was the basal roughage, while maize, wheat bran and cotton seed cake were the energy and protein supplements in different proportions. Table 1 shows the composition of the experimental ration. The experimental feeding which continued for 93 days was terminated with a 7-day metabolism trial. Trace mineralized salt blocks and clean water were made available to the lambs throughout the experimental period. All animals were weighed weekly and the mean of the initial and final weights were used to calculate metabolic size.

During the metabolism trial, the total wet faeces voided were weighed daily and dried in forced-draught oven at $80^{\circ} \mathrm{C}$ for 
ADU

TABLE 1

Composition of rations fed.

\begin{tabular}{ccccc}
\hline Low Energy & Low Energy & High Energy & High Energy \\
Low protein & High protein & Low protein & High protein \\
$(L L)$ & $(L H)$ & $(H L)$ & $(H H)$
\end{tabular}

Feed composition \%

$\begin{array}{lrrrr}\text { Groundnut top hay } & 48.6 & 44.2 & 11.6 & 6.9 \\ \text { Maize } & 25.8 & 23.2 & 65.2 & 62.4 \\ \text { Wheat bran } & 20.0 & 20.0 & 20.0 & 20.0 \\ \text { Cotton seed cake } & 4.6 & 11.6 & 2.2 & 9.7 \\ \text { Vitamin and Mineral Premix a } & 1.0 & 1.0 & 1.0 & 1.0 \\ \text { Chemical composition } b & & & & \\ \text { Crude protein, \% } & 11.2 & 15.9 & 11.5 & 16.4 \\ \text { Metabolizable energy, Mcal/kg } & 2.4 & 2.4 & 2.9 & 2.9 \\ \text { Chemical composition } & & & & \\ \text { Dry matter \% } & 94.1 & 95.5 & 97.8 & 95.2 \\ \text { Crude protein \%0 } & 11.0 & 15.4 & 11.2 & 16.1 \\ \text { Metabolizable energy, Mcal/kg } & 2.49 & 2.44 & 2.93 & 2.95\end{array}$

a. Manufactured with the technical assistance of F. Hoffman La Roche and Co. Ltd., Basle, Switzeland.

b. Calculated.

c. Determined.

36 hours. The dried samples for 7 days were bulked, milled and kept in air-tight containers until required for analyses. Similarly, daily urine output were collected in trays wetted with $10 \mathrm{ml}$ toluene to prevent nitrogenous breakdown. Daily output was measured and a $10 \%$ aliquot of daily output was bulked for 7 days and stored at $-5^{\circ} \mathrm{C}$.

The procedure for chemical analyses of feeds, faeces and urine were as described by Adu and Adamu (1982). The proximate composition of the experimental diets is given in Table 1.

\section{RESULTS AND DISCUSSION}

Animals receiving the High energy low protein (HL) ration has the highest dry matter intake of $566.2 \mathrm{~g} /$ day as against the lowest intake of 463.4 day by animals on the low energy low protein (LL) ration; the differences were significant $(P / 0.05)$. Dry matter intake per $100 \mathrm{~kg}$ body weight was the same for low energy high protein (LH) nd HL rations. Animals on the low energy ration consumed more dry matter from groundnut top hay (the basal roughiage) than those on the high energy rations. Although the differences were not significant, the result tended to show that the intake of roughage is reduced when high energy feeds are given; within each energy level, the intake of the hay decreased with increase in protein level. This seem to conflict with the reports of Crabtree and Williams (1971 a, b) that the intake of hay increased with increase in crude protein content of the concentrate feed. Perhaps a plausible explanation for 


\section{ADU}

the present result is that the hay used in this study is of medium quality with a crude protein content of $10.63 \%$.

Within each energy level, apparent dry matter digestibility increased with increase in the protein level and irrespective of the protein level, dry matter digestibility was $7-18 \%$ higher on high energy rations than on low energy rations. Similar results have been reported by Walker and Cook (1967) and Singh et al (1979). Crude protein level significantly (PQ0.01) increased crude protein digestibility. Within each energy level crude protein digestibility was higher by 11.8 and $17.8 \%$. Similar findings have been reported by Walker and Cook (1967); Singh et al (1970, 1979). Energy level per se did not affect crude protein digestibility. On the high energyhigh protein (HH) diet, crude fibre digestibility was depressed to $37 \%$ as against $42 \%$ in the high energy-low pro- tein (HL) diet. The differences were however not significant.

Within each energy level, nitrogen intake increased with increase in crude protein level, although the increase was significantly $(P<0.05)$ higher $(4.65 \mathrm{~g})$ in the low energy ration than in the high energy ration $(1.89 \mathrm{~g})$. However, nitrogen retention was significantly $(P<0.05)$ more on the high energy ration than on the low energy ration. Within energy levels, there were not significant differences in the amount of energy retained.

Live weight gain was highest in the $\mathrm{LH}$ group and lowest in the LL group. Within each energy level, liveweight gain increased with increase in protein level. The fact that all the lambs had weight gains indicated that the intake of energy and protein was above maintenance requirements. In fact calculated digestible energy intakes in the present study were

TABLE 2.

Feed nutrient digestibility and utilization

\begin{tabular}{|c|c|c|c|c|}
\hline & $\begin{array}{c}\text { Low Energy } \\
\text { Low protein } \\
(L L)\end{array}$ & $\begin{array}{l}\text { Low Energy } \\
\text { High protein } \\
\text { (LH) }\end{array}$ & $\begin{array}{c}\text { High Energy } \\
\text { Low protein } \\
(H L)\end{array}$ & $\begin{array}{c}\text { High Energy } \\
\text { High protein } \\
\text { (HH) }\end{array}$ \\
\hline Dry matter intake, $\mathrm{g} /$ day & $463.4 \pm 3.8^{b}$ & $541.7 \pm 7.8^{a}$ & $566.2 \pm 6.9^{\mathrm{a}}$ & $458.6 \pm 9.1^{b}$ \\
\hline \multicolumn{5}{|l|}{ Dry matter intake $/ 100 \mathrm{~kg}$ body weight, } \\
\hline 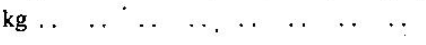 & $2.53^{*}$ & 2.60 & 2.60 & 2.41 \\
\hline \multicolumn{5}{|l|}{ Dry matter intake from hay, $g(\%$ of } \\
\hline $\begin{array}{llllll}\text { total intake) } \ldots & \ldots & \ldots & \ldots & \ldots & \ldots\end{array}$ & $61.5^{\mathrm{a}}$ & $16.3^{\mathrm{a}}$ & $47.6^{\mathrm{b}}$ & $26.1^{\mathrm{c}}$ \\
\hline Liveweight gain, g/day & $56.4 \pm 0.24 b$ & $79.1 \pm 0.38 \mathrm{a}$ & $65.8 \pm 0.09^{a}$ & $67.1 \pm 0.70^{\mathrm{a}}$ \\
\hline \multicolumn{5}{|l|}{ Apparent Digestibility Coefficient, $\%$} \\
\hline $\begin{array}{lllll}\text { Dry Matter } & . & \ldots & \ldots & \ldots\end{array}$ & $46.8 \pm 0.70$ & $51.5 \pm 0.97$ & $59.5 \pm 1.08$ & $64.8 \pm 1.42$ \\
\hline $\begin{array}{llll}\text { Crude protein } \ldots & \ldots & \ldots & \ldots\end{array}$ & $59.4 \pm 1.14^{d}$ & $71.2 \pm 3.14^{\mathrm{c}}$ & $60.6 \pm 2.14^{\mathrm{d}}$ & $78.4 \pm 3.7 \mathrm{r}^{\mathrm{C}}$ \\
\hline Crude fibre & $44.2 \pm 0.81$ & $43.6 \pm 0.67$ & $42.1 \pm 0.61$ & $36.8 \pm 0.38$ \\
\hline \multicolumn{5}{|l|}{ Nitrogen balance } \\
\hline Nitrogen intake, g/day & $8.49 \pm 0.19 b$ & $13.14 \pm 1.78^{\mathrm{a}}$ & $10.35 \pm 0.31 \mathrm{~b}$ & $12.24 \pm 0.27^{\mathrm{a}}$ \\
\hline Nitrogen balance g/day & $1.23 \pm 0: 38^{b}$ & $2.93 \pm 0.51^{b}$ & $4.1 \pm 0.27 \mathrm{a}$ & $4.7 \pm 0.34^{\mathrm{a}}$ \\
\hline Calculated nutrient intake & & & & \\
\hline Digestible crude protein $\mathrm{g} / \mathrm{wkg} 0.75$ & $\cdot 4.04$ & 6.04 & 6.12 & 6.89 \\
\hline Digestible energy, Mcal/wkg 0.75 & 0.13 & 0.14 & 0.18 & 0.15 \\
\hline
\end{tabular}

+ Figures in the same row with different superscripts differ significantly $(a, b$ at $5 \%$ c,d at $1 \%)$. 
above the maintenance requirement reported by Garret, Meyer and Lofgrean (1959); A.R.G. (1965), N.R.C. (1968), Wallace (1968) and Adu (1975). Also, the calculated digestible crude protein requirement were in most rations used in the present study similar to the figure reported for maintenance and grwoth by Ikhatua and Adu (1981) for Yankasa lambs. On the whole it would appear that animals fed high energy rations apparently required more protein than those fed low energy rations.

\section{ACKNOWLEDGEMENT}

The author is grateful to the Director of the National Animal Production Research Institute for facilities to carry out this work and for permission to publish the results.

\section{REFERENCES}

ADU, I.F. 1975. The effects of 'steaming up' on the birth-weight, lactation and growth of West African Dwarf Sheep. Ph.D Thesis University of Ibadan, Nigeria.

ADU, I.F. and LAKPINI, C.A.M. 1980. Nitrogen utilization by pregnant Yankasa sheep. Nig. J. Anim. Prod. $7(2)$ in press.

ADU, I.F. and ADAmu, A.M. 1982. Nutritive value and utilization of three tropical grass hays by sheep. Tropical Grassland 16: 29-23.

Agricultural Research Council 1965. The nutrient requirements of farm livestock. No. 2 Ruminants ARC, London.

Cramption, E.W. 1964. Nutrient to calorie ratios in applied nutrition. J. Nutr. 82: 353-358.

Ferrell C.C., Kohimeier, R.H. Crowe, J.D. and HudSON GLIMP 1978. Influence of dietary energy, protein and biological type of steer upon rate of gain and carcass characteristics. J. Anim. Sci. 46: 755-270.

Garret, W.N., Meyer, J.H. and Lofgreen, G.P. 1959. The comparative energy requirements of sheep and cattle for maintenance and gain $\mathrm{J}$. Anim. Sci. 18: 523-530.

IKHATUA, U.J. and ADU, I.F. 1981. Protein requirement of weaned Yankasa lambs for maintenance and growth J. Anim. Prod. Res. 1: 13-22.

JONES, J.R. and HoGVE, D.E. 1960. Effect of energy level on the protein requirement of lambs fattened with or without stilbestrol J. Anim. Sci. 19: 1049-1054.

National Research Council 1968, Nutrient requirements of domestic animals No. 5 nutrient requirements of sheep 4 th edition Washington, D.C.

Preston, R.C. 1966. Protein requirements of growing and finishing cattle. J. Nutr. 20: 1590161.

Prior, R.C. Koylmerier, R.H., Cundiff, L.V., Dikeman, M.E. and CROuSE, J.D. 1977. Influence of dietary energy and protein on growth and carcass composition of different biological types of cattle. J. Anim. Sci. 45: $132-$

Singh, M; Mahadevan, V. and Agarwal ON. 1970. Utilization of nutrients at three levels of protein intake in adult sheep Indian J. Anim. Hlth. 9: 63-67.

Singh, N.P., Singh, M. and Patriayak, B.C. 1979. Effect of energy and protein levels on nutrient digestibility and wool production. Indian J. Anim. Sci. 49: 277-281.

WALKeR, D.M. and CoOK, L.J. 1967. Nitrogen balance studies with milk fed lambs 4 . Effect of different nitrogen and sulphur intakes on liveweight gain wool growth and on nitrogen and sulphur balances. Br. J. Nutr. 237-241.

WALLACE, L.R. 1948. The growth of lambs before after birth in relation to the level of nutrition. $J$. Agric. Sci. Camb. 38: 93-153; 242-302, 362-401. 